\title{
Efektivitas Model Pembelajaran Blended Learning untuk Meningkatkan Hasil Belajar Geografi pada Materi Litosfer Kelas X SMA
}

\author{
Rasti Fajar Peni Riantika ${ }^{1}$, Mukminan ${ }^{1}$ \\ ${ }^{1}$ Pendidikan Geografi-Universitas Negeri Yogyakarta
}

\begin{tabular}{l}
\hline \hline INFO ARTIKEL \\
\hline Riwayat Artikel: \\
Diterima: $16-09-2019$ \\
Disetujui: $18-12-2019$
\end{tabular}

\section{Kata kunci:}

blended learning; geography learning outcomes; high school student blended learning; hasil belajar geografi; siswa SMA

\author{
Alamat Korespondensi: \\ Rasti Fajar Peni Riantika \\ Pendidikan Geografi \\ Universitas Negeri Yogyakarta \\ Jalan Colombo. No. 1, Karangmalang, Caturtunggal, Kecamatan Depok, Kabupaten Sleman, Daerah Istimewa Yogyakarta \\ E-mail: rastifajar.2018@student.uny.ac.id
} Menurut Undang-undang Sistem Pendidikan Nasional Indonesia No, 20 tahun 2003 Pendidikan Nasional bertujuan untuk mengembangkan potensi peserta didik agar menjadi manusia yang beriman dan bertakwa kepada Tuhan yang Maha Esa, berakhlak mulia, sehat, berilmu, cakap, kreatif, mandiri dan menjadi warga negara yang demokratis dan bertanggung jawab. Sesuai dengan tujuan pendidikan nasional tersebut, maka diperlukan model pembelajaran yang kreatif, bervariasi, dan lebih terfokus dalam mengembangkan peserta didiknya menjadi lebih aktif dalam proses pembelajaran. Model pembelajaran bertujuan untuk menciptakan kondisi yang memungkinkan siswa untuk belajar sehingga tercapainya hasil belajar yang optimal.

Model pembelajaran yang diterapkan di sekolah menengah sebagian besar bersifat konvensional. Ciri-ciri pembelajaran konvensional menurut (Wallace, 1992) meliputi (1) otoritas seorang guru lebih diutamakan dan memilili peran menjadi tadan bagi siswanya, (2) kurangnya minat siswa karena perhatian kepada masing-masing individu sangat kecil, (3) pembelajaran yang ada di sekolah dianggap sebagai persiapan masa yang akan datang, tidak dipandang dari kemampuan meningkatnya kompetensi siswa pada saat ini, dan (4) yang mendasari pembelajaran konvensional adalah berorientasi pada keberhasilan tujuan dan mengesampingkan pengembangan potensi siswa. Model pembelajaran konvensional kurang fleksibel dalam mengakomodasi perkembangan materi kompetensi karena guru harus intensif menyesuaikan materi pelajaran dengan perkembangan teknologi terbaru (Sodikin, Noesasongko, \& Pramudi, 2009).

\begin{abstract}
This study aims to determine: The Effectiveness of the Blended Learning Leadel to improve geography learning outcomes in lithosphere class X SMA Pretest-posttest Control Group Design. The results showed that the Blended Learning evidenced by testing the hypothesis obtained $\mathrm{p}$ value of 0,000 , which means the results of significance at $\alpha<0.05$. Geography learning results using the Blended Learning higher experimental class proves that the results of geography learning on lithospheric

Abstrak: Penelitian ini bertujuan untuk mengetahui efektivitas model pembelajaran Blended Learning untuk meningkatkan hasil belajar Geografi pada materi litosfer kelas X SMA. Penelitian ini merupakan penelitian eksperimen dengan responden 17 siswa Penelitian yang digunakan adalah Pretest-posttest Control Group Design. Hasil penelitian menunjukkan model pembelajaran Blended Learning lebih efektif hipotesis diperoleh nilai $\mathrm{p}$ sebesar 0,000 yang berarti hasil signifikansi pada $\alpha<0,05$. Hasil belajar geografi menggunakan model pembelajaran Blended Learning lebih tinggi dibanding menggunakan model konvensional. Rerata nilai pre-test dan post-test kelas pretest dan posttest kelas kontrol sebesar 1,50 . Kenaikan rerata kelas eksperimen yang ebih tinggi membuktikan bahwa hasil belajar Geografi menggunakan mode pembelajaran Blended Learning lebih baik peningkatannya dibanding menggunakan model konvensional.
\end{abstract}


Akibat sistem pembelajaran konvensional adalah peserta didik mengantuk atau mengobrol di kelas ketika pembelajaran berlangsung, kurang konsentrasinya peserta didik terhadap penjelasan yang disampaikan oleh guru, rasa ingin tahu peserta didik belum terbangun, peserta didik tidak berani berargumentasi atau bersifat pasif di kelas. Peserta didik yang menomerduakan pelajaran, menurut (Mukminan, 2014). Geografi untuk jenjang SMA/MA ditetapkan menjadi bagian dari kelompok mata pelajaran peminatan yang bertujuan memberikan kesempatan kepada peserta didik mengembangkan minatnya dalam sekelompok mata pelajaran sesuai dengan minat keilmuannya di perguruan tinggi, dan mengembangkan minatnya terhadap suatu disiplin ilmu atau ketrampilan tertentu. Sehingga menyebabkan siswa yang fokus hanya siswa yang mengambil mata pelajaran pilihan Geografi. Hal tersebut menuntut guru mata pelajaran Geografi untuk memiliki kemampuan mengkolaborasikan model pembelajaran yang lebih menarik dan kontekstual dengan tujuan siswa dapat lebih memahami materi yang telah disampaikan dengan optimal. Menurut (Sanjaya, 2016) menyatakan bahwa pada pembelajaran konvensional siswa ditempatkan sebagai obyek belajar yang berperan sebagai penerima informasi secara pasif. Jadi, pada umumnya penyampaian pelajaran menggunakan metode ceramah, tanya jawab dan penugasan. Dengan demikian, dapat disimpulkan bahwa model pembelajaran konvensional merupakan pembelajaran yang terpusat pada guru, mengutamakan hasil bukan proses, siswa ditempatkan sebagai objek dan bukan subjek pembelajaran sehingga siswa sulit untuk menyampaikan pendapatnya (Ibrahim, 2017).

Secara historis, para pendidik telah memikirkan pola pembelajaran yang dilaksanakan secara tatap muka dengan mediasi komputer, atau pembelajaran yang terdiri dari sebuah kombinasi tatap muka dan format pembelajaran yang dilakukan dengan menggunakan perangkat komputer yang disebut dengan blended learning (Graham, 2006). Model Blended Learning merupakan bagian dari e-learning dengan memadukan pembelajaran online dengan offline (tatap muka). Pembelajaran online pada Blended Learning mengupayakan pembelajaran dengan mengintegrasikan teknologi sehingga dapat meningkatkan kualitas belajar (Qamar et al., 2018). (Husamah, 2014) juga mengungkapkan bahwa blended learning merupakan perpaduan dari teknologi multimedia, CD Room, video streaming, kelas virtual, voice-mail, e-mail, telekonferensi, dan animasi teks online. Blended learning berarti gabungan antara sistem pembelajaran tatap muka (face to face) dengan pembelajaran elearning yang dapat digunakan oleh siapa saja (everyone), di mana saja (everywhere), kapan saja (anytime). Istilah Blended Learning mengandung arti percampuran atau kombinasi pembelajaran atau perpaduan dari unsur-unsur pembelajaran tatap muka langsung dan daring secara harmonis dan padu yang ideal (Heinze et al., 2007). Sistem blended learning selama ini masih didefinisikan sebagai kombinasi model pembelajaran yang membagi porsi pembelajaran secara tradisional dan daring secara terpisah, padahal ada kemungkinan untuk menggabungkan pembelajaran tradisional dan pembelajaran online secara bersamaan di dalam kelas (Mujiono et al., 2018). Penerapkan model pendekatan blended learning mengalami peningkatan hasil belajar baik dari segi peningkatan nilai, penggunaan waktu, dan kemenarikan (Jamaluddin et al., 2018). Model pembelajaran ini menemukan cara mencapai tujuan pembelajaran dan menyediakan pengalaman belajar dan mengajar sebaik mungkin (Waty et al., 2018). Semua ini dikombinasikan dengan bentuk tradisional pelatihan di kelas dan pelatihan perorangan. Dalam hal ini blended learning merupakan suatu solusi yang tepat untuk proses pembelajaran yang sesuai, tidak hanya dengan kebutuhan pembelajaran namun juga gaya belajar peserta didik.

Hasil penelitian dari (Sudarman \& Mulawarman, 2018) menunjukkan bahwa penggunaan strategi pembelajaran Blended Learning secara signifikan lebih baik daripada strategi pembelajaran tatap muka dalam memberikan perolehan belajar konsep. Hasil penelitian (Hermawanto et al., 2013) juga membuktikan bahwa adanya peningkatan pemahaman siswa dengan penerapan pembelajaran model Blended Learning rata-rata peningkatan 37,59. Layanan informasi dengan menggunakan model pembelajaran blended learning efektif meningkatkan motivasi dan hasil belajar siswa (Fitri et al., 2016). Hasil observasi awal Kegiatan Belajar Mengajar di SMA Islam Surakarta untuk materi dinamika litosfer dengan model pembelajaran langsung tatap muka dengan metode konvensional dan tanya jawab kurang dapat membangkitkan aktivitas siswa dalam belajar, hasil belajar menunjukkan 75\% siswa memperoleh nilai di bawah Kriteria Ketuntasan Minimal, dan hanya $25 \%$ siswa yang memperoleh nilai di atas KKM. Hasil belajar Geografi tersebut dapat mencerminkan bahwa pemilihan dan penerapan model pembelajaran konvensional dalam proses pembelajaran belum dapat memengaruhi penguasaan materi yang diajarkan. Oleh karena itu, diperlukan usaha yang serius dalam membangun pemahaman siswa dan aktivitas belajar siswa terhadap materi dinamika litosfer. Usaha yang dilakukan adalah dengan menerapkan blended learning atau kolaborasi pembelajaran langsung dengan perangkat pembelajaran berbasis e-learning yang bertujuan untuk menghilangkan kejenuhan siswa dan meningkatkan hasil belajar.

Pembelajaran Geografi dengan blended learning sebagai salah satu model pembelajaran kontekstual sangat baik diterapkan karena dapat meningkatkan kemampuan berpikir dan bernalar siswa dalam mengenali masalah, menganalisis, menemukan solusi, dan mengevaluasi permasalahan kependudukan disekitar siswa sehingga dapat berpengaruh terhadap hasil pembelajaran yang lebih baik (Alfi et al., 2016). Berdasarkan permasalahan tersebut, maka tujuan penelitian ini adalah mempelajari efektivitas model pembelajaran Blended Learning untuk meningkatkan hasil belajar Geografi pada materi litosfer kelas X SMA Islam Surakarta". Hasil dari penelitian ini berkontribusi untuk memberikan pandangan terhadap tenaga pendidik untuk mengembangkan model pembelajaran Blended Learning dalam proses kegiatan belajar mengajar dengan tujuan siswa dapat mengeksplorasi pengetahuan lebih banyak dari proses tatap muka. 


\section{METODE \\ Subjek Penelitian}

Penelitian ini merupakan penelitian eksperimen untuk mengetahui efektivitas model pembelajaran Blended Learning untuk meningkatkan hasil belajar Geografi pada materi litosfer kelas X SMA. Subjek penelitian adalah siswa kelas X SMA Islam Surakarta yaitu siswa kelas XI IPS 1 dan siswa kelas XI IPS 2. Penentuan kedua kelas ini dipilih dengan pertimbangan nilai rata-rata kedua kelas relatif setara dan jumlah 17 siswa pada kelompok kontrol dan 17 siswa pada kelompok eksperimen. Subjek penelitian terdiri atas dua kelas dengan kondisi homogen karena mempunyai tingkat prestasi yang sama, yaitu kelas eksperimen dan kontrol.

\section{Langkah Penelitian}

Sebelum diberi perlakuan, siswa dari kelas eksperimen dan kontrol diberi soal pretest untuk mengetahui kemampuan awal siswa, selanjutnya diberi perlakuan yang berbeda pada kelas eksperimen dan kelas kontrol. Pada kelas eksperimen diterapkan pembelajaran dengan model pembelajaran Blended Learning, sedangkan kelas kontrol diterapkan pembelajaran dengan model pembelajaran konvensional. Blended Learning yang digunakan pada penelitian ini adalah mengkombinasikan pembelajaran dalam kelas didukung dengan penggunaan aplikasi Telegram.

Langkah-langkah penerapan model pembelajaran Blended Learning adalah sebagai berikut. Pertama, siswa menginstal aplikasi Telegram pada smartphone atau laptop masing-masing. Kedua, siswa membuat akun pada aplikasi Telegram. Ketiga, siswa bergabung dalam grup pembelajaran Geografi yang telah dibuat oleh peneliti dengan materi Litosfer. Keempat, siswa mengikuti pembelajaran dalam grup mata pelajaran Geografi pada aplikasi Telegram.

\section{Instrumen Penelitian}

Instrumen dalam penelitian ini berupa soal pretest dan postest berupa 25 soal pilihan ganda dengan lima pilihan jawaban.

\section{Analisis Data}

Analisis data yang digunakan meliputi (a) uji normalitas, (b) uji homogenitas, dan (c) uji hipotesis. Pertama, Uji Normalitas. Perhitungan normalitas bertujuan untuk mengetahui apakah data pada kedua kelas berasal dari populasi yang berdistribusi normal atau tidak. Perhitungan normalitas dihitung menggunakan software SPSS versi 20 for windows dengan menggunakan uji Shapiro-Wilk. Data yang dihitung normalitasnya adalah data pre-test dan post-test hasil belajar siswa di kelas eksperimen dan kontrol. Kriteria hasil perhitungan normalitas yaitu, apabila nilai signifikansi (sig) $>0,05$ berarti data tersebut berdistribusi normal. Jika nilai sig $<0,05$ berarti data tersebut tidak berdistribusi normal.

Kedua, Uji Homogenitas.Perhitungan homogenitas digunakan untuk menghitung apakah data yang dibandingkan memiliki varians yang homogen atau tidak. Perhitungan homogenitas dilakukan dengan menggunakan uji levene. Kriteria perhitungan homogenitas yaitu apabila nilai sig $>0,05$ maka data tersebut homogen. Jika memperoleh signifikansi $<0,05$ maka data yang diperoleh tidak homogen. Perhitungan homogenitas dilakukan pada data pre-test post-test hasil belajar siswa di kelas eksperimen maupun kontrol. Perhitungan homogenitas menggunakan software SPSS.

Ketiga, Uji Hipotesis. Pengujian hipotesis bertujuan untuk mengetahui efektivitas Model pembelajaran Blended Learning dibandingkan dengan model pembelajaran konvensional terhadap hasil belajar siswa pada pembelajaran Geografi. Penelitian ini akan menguji hipotesis yang diajukan, yaitu Ha: Model pembelajaran Blended Learning efektif untuk meningkatkan hasil belajar geografi pada materi litosfer kelas X di SMA Islam 1 Surakarta. Ho: Model pembelajaran Blended Learning tidak efektif untuk meningkatkan hasil belajar Geografi pada materi litosfer kelas X di SMA Islam 1 Surakarta.

\section{HASIL}

\section{Hasil Pre-test Kemampuan Awal Siswa Kelas Kontrol dan KelasEksperimen}

Kelas kontrol dan kelas eksperimen terlebih dahulu dilakukan pre-test kemampuan awal siswa sebelum berlangsungnya proses pembelajaran. Pre-test tersebut bertujuan untuk mengetahui kemampuan awal hasil belajar siswa di kelas kontrol dan kelas eksperimen. Tes yang dilakukan berupa 25 soal pilihan ganda dengan materi Litosfer. Data kemampuan awal siswa di kelas kontrol dan kelas eksperimen dapat dilihat pada tabel 1.

Berdasarkan tabel 1, dapat diketahui bahwa data pre-test kemampuan awal siswa kelas kontrol memperoleh nilai tertinggi 82,00 dan nilai terendah 52,00, kelas eksperimen memperoleh nilai tertinggi 80,00 dan nilai terendah 52,00. Nilai rerata pre-test kelas kontrol 66,35 dengan simpangan baku 9,17, kelas eksperimen 67,52 dan simpangan bakunya 7,194. Perolehan pre-test kemampuan awal siswa kelas kontrol dan kelas eksperimen dapat diidentifikasi katagori kecenderungan seperti pada tabel 2 . 
Tabel 1. Data Pre-test Kemampuan Awal Siswa Kelas Kontrol dan Kelas Eksperimen

\begin{tabular}{clcc}
\hline No & Data & Kelas Kontrol & Kelas Eksperimen \\
\hline 1 & N & 17 & 17,00 \\
2 & Nilai Min & 52,00 & 52,00 \\
3 & Nilai Max & 82,00 & 80,00 \\
4 & Mean & 66,35 & 67,52 \\
5 & Simpangan Baku & 9,17 & 7,19 \\
\hline
\end{tabular}

Tabel 2. Kategori Pre-test Kemampuan Awal Siswa Kelas Kontrol dan Kelas Eksperimen

\begin{tabular}{cccrcc}
\hline Interval & f & Persentase Kelas Kontrol & f & Persentase Kelas Eksperimen & Kategori \\
\hline $\mathrm{x}<6$ & 6 & $35,29 \%$ & 4 & $23,52 \%$ & Rendah \\
$6 \mathrm{x}<7,5$ & 7 & $41,17 \%$ & 10 & $58,82 \%$ & Sedang \\
$\mathrm{x}>7,5$ & 4 & $21,52 \%$ & 3 & $17,64 \%$ & Tinggi \\
Jumlah & 17 & & 17 & & \\
\hline
\end{tabular}

Berdasarkan tabel 2 dapat diketahui bahwa nilai pre-test siswa kontrol terdapat enam siswa (35,29\%), kelas eksperimen terdapat empat siswa $(23,52 \%)$ termasuk kategori rendah, kelas kontrol terdapat tujuh siswa $(41,17 \%)$ dan kelas eksperimen terdapat 10 siswa $(58,82 \%)$ katagori sedang, dan empat siswa $(21,52 \%)$ kelas kontrol tiga siswa $(17,64 \%)$ kelas eksperimen masuk kategori tinggi.

\section{Post-test Hasil belajar Siswa Kelas Kontrol dan Kelas Eksperimen}

Setelah berlangsungnya pembelajaran terhadap kedua kelas, yaitu kelas kontrol dan kelas eksperimen maka siswa kembali diberikan post-test hasil belajar. Post-test tersebut bertujuan untuk mengetahui kemampuan akhir hasil belajar siswa di kelas kontrol dan kelas eksperimen. Tes yang diberikan berupa 25 soal pilihan ganda dengan materi litosfer. Data post-test hasil belajar siswa di kelas kontrol dan kelas eksperimen dapat dilihat pada tabel 3 .

Tabel 3. Data Post-test Hasil Belajar Kelas Kontrol dan Kelas Eksperimen

\begin{tabular}{clcc}
\hline No & Data & Kelas Kontrol & Kelas Eksperimen \\
\hline 1 & N & 17,00 & 17,00 \\
2 & Nilai Min & 58,00 & 64,00 \\
3 & Nilai Max & 80,00 & 92,00 \\
4 & Mean & 67,88 & 80,23 \\
5 & Simpangan Baku (Sd) & 6,34 & 7,13 \\
\hline
\end{tabular}

Berdasarkan tabel 3 dapat diketahui bahwa data nilai tertinggi post-test hasil belajar siswa di kelas kontrol memperoleh nilai 80,00, kelas eksperimen memperoleh nilai 92,00. Nilai terendah kelas kontrol adalah 58,00, kelas eksperimen adalah 64,00. Nilai rerata yang diperoleh kelas kontrol adalah 67,88, kelas eksperimen 80,22 dan simpangan baku kelas kontrol 6,34, kelas eksperimen 7, 13. Perolehan data post-test hasil belajar siswa kelas kontrol dan kelas eksperimen yang diperoleh dari instrumen tes dapat diidentifikasi ketegori kecenderungan seperti pada tabel 4.

Tabel 4. Kategori Post-Test Hasil Belajar Kelas Kontrol dan Kelas Eksperimen

\begin{tabular}{clclcl}
\hline Interval & $\mathbf{f}$ & Kelas Kontrol Prosentase & $\mathbf{f}$ & Kelas Eksperimen Prosentase & Kategori \\
\hline $\mathrm{x}<6,5$ & 7 & $41,18 \%$ & 1 & $5,88 \%$ & Rendah \\
$6,5 \mathrm{x}<7,5$ & 8 & $47,05 \%$ & 7 & $41,18 \%$ & Sedang \\
$\mathrm{x}>7,5$ & 2 & $11,76 \%$ & 9 & $52,94 \%$ & Tinggi \\
Jumlah & 17 & & 17 & & \\
\hline
\end{tabular}

Berdasarkan tabel 4 dapat diketahui bahwa pada data kecenderungan nilai post-test siswa kelas kontrol terdapat tujuh siswa $(41,18 \%)$, kelas eksperimen terdapat satu siswa $(5,88 \%)$ termasuk kategori rendah, kelas kontrol terdapat delapan siswa $(47,05)$, kelas eksperimen terdapat tujuh siswa $(41,18 \%)$ termasuk kategori sedang dan kelas kontrol terdapat dua siswa $(11,76 \%)$, kelas eksperimen terdapat sembilan siswa $(52,94 \%)$ termasuk kategori tinggi. 


\section{Efektivitas Model Pembelajaran Blended Learning untuk Meningkatkan Hasil Belajar Geografi Hasil Pengujian Normalitas}

Perhitungan uji normalitas tes menggunakan data pre-test dan post-test hasil belajar di kelas eksperimen dan kontrol. Hasil perhitungan menggunakan software SPSS versi 20 for windows dapat disimak pada tabel 9.

Tabel 9. Uji Normalitas

\begin{tabular}{llcc}
\hline Kelompok & Data & $\boldsymbol{p}$ & Kesimpulan \\
\hline Kontrol & Pre-test & 0,276 & Normal \\
Kontrol & Post-test & 0,195 & Normal \\
Eksperimen & Pre-test & 0,739 & Normal \\
Eksperimen & Post-test & 0,251 & Normal \\
\hline
\end{tabular}

Berdasarkan tabel 9 diketahui pada data pre-test hasil belajar di kelas eksperimen diperoleh nilai sig Shapiro-wilk 0,739. Nilai sig 0,739>0,05 berarti data pre-test kelas eksperimen berdistribusi normal. Data post-test hasil belajar kelas eksperimen diperoleh nilai sig Shapiro-wilk 0,251. Nilai sig 0,251 >0,05 berarti data post-test kelas eksperimen berdistribusi normal. Data pre-test hasil belajar pada kelas kontrol diperoleh nilai sig Shapiro-wilk 0,276. Nilai sig 0,276>0,05 berarti data pre-test hasil belajar pada kelas kontrol menunjukkan berdistribusi normal. Nilai post-test kelas kontrol diperoleh nilai sig Shapiro-wilk 0,195. Nilai sig 0,195 > 0,05 hal ini menunjukkan bahwa data post-test kelas kontrol berdistribusi normal. Data di atas menunjukkan bahwa data pre-test dan post-test hasil belajar siswa di kelas kontrol maupun eksperimen berdistribusi normal dan memenuhi syarat untuk pengujian statistik.

\section{Hasil Pengujian Homogenitas}

Tabel 10. Hasil Uji Homogenitas

\begin{tabular}{llcccc}
\hline Kelompok & Data & Levene Statistic & & Sig & Kesimpulan \\
\hline Kontrol & Pre-test & 0,189 & $>$ & 0,670 & Homogen \\
Kontrol & Post-test & 1,467 & $>$ & 0,244 & Homogen \\
Eksperimen & Pre-test & 0,043 & $>$ & 0,839 & Homogen \\
Eksperimen & Post-test & 0,234 & $>$ & 0,635 & Homogen \\
\hline
\end{tabular}

Perhitungan homogenitas menggunakan data pre-test dan post-test hasil belajar di kelas eksperimen dan kontrol. Hasil perhitungan diketahui pre-test kelas eksperimen hasil belajar diperoleh nilai levene statistic 0,043 dengan sig 0,839. Nilai sig 0,839>0,05 menunjukkan bahwa data pre-test di kelas eksperimen memiliki varians yang homogen. Pada post-test kelas eksperimen hasil belajar diperoleh nilai levene statistic 0,234 dengan sig 0,635. Nilai sig 0,635>0,05 menunjukkan bahwa data post-test di kelas eksperimen memiliki varians yang homogen. Hasil perhitungan pada pre-test kelas kontrol hasil belajar nilai levene statistic 0,189 dengan sig 0,670. Nilai sig 0,670>0,05 menunjukkan bahwa data pre-test di kelas kontrol memiliki varians yang homogen. Hasil perhitungan pada posttest kelas kontrol hasil belajar levegne statistic 1,467 dengan sig 0,244. Nilai sig 0,244> 0,05 menunjukan bahwa data pretest di kelas kontrol memiliki varians yang homogen.

\section{Uji Hipotesis}

Tabel 11. Hasil Uji Hipotesis dengan Paired Sample t-test $(\alpha=0,05 \%)$

\begin{tabular}{llccl}
\hline & Kelas Kontrol & Kelas Eksperimen & Taraf Sig & Keterangan \\
\hline Pre-Test & 66,35 & 67,52 & 0,680 & Tidak ada perbedaan \\
Post-Test & 67,88 & 80,23 & 0,000 & Terdapat perbedaan yang signifikan \\
\hline
\end{tabular}

Berdasarkan tabel 10 menunjukkan bahwa nilai sig. 0,680>0,05 sehingga tidak ada perbedaan hasil belajar di kelas eksperimen dan kelas kontrol sebelum diberikan perlakuan. Sementara itu, hasil perhitungan Post-Test diperoleh nilai sig. 0,000 $<0,05$ sehingga terdapat perbedaan yang signifikan hasil belajar siswa dengan model pembelajaran Blended Learning dan model pembelajaran konvensional pada pembelajaran Geografi. Adanya pembelajaran yang signifikan hasil belajar siswa dengan model pembelajaran Blended Learning dan model pembelajaran konvensional menunjukkan bahwa model pembelajaran Blended Learning lebih efektif daripada model pembelajaran konvensional. 


\section{PEMBAHASAN}

Berdasarkan tabel 10 hasil belajar siswa kelas kontrol dan eksperimen berbeda, hal ini dapat dilihat pada perbedaan nilai rata-rata dari kedua kelas tersebut dan kelas eksperimen lebih unggul dibandingkan dengan kelas kontrol. Perbedaan hasil belajar pada kelas kontrol dan kelas eksperimen disebabkan oleh perbedaan model pembelajaran yang diterapkan. Pada kelas kontrol yang tidak menerapkan model pembelajaran blended learning. Pada kelas kontrol guru menggunakan model pembelajaran konvensional yaitu guru memberikan penjelasan materi hanya pada saat jam pembelajaran di kelas saja. Pembelajaran berlangsung satu arah yang menyebabkan beberapa siswa masih belum memahami materi. Siswa yang masih belum memahami penjelasan materi di dalam kelas memiliki keterbatasan waktu pembelajaran yang hanya dua pertemuan saja tiap minggunya.

Pada kelas eksperimen menggunakan model pembelajaran Blended learning, siswa yang belum memahami penjelasan materi di dalam kelas dapat berinteraksi dengan guru melalui kelas virtual (pembelajaran daring). Penerapan model pembelajaran Blended Learning siswa memiliki waktu yang lebih banyak untuk berinteraksi dengan guru. Sehingga siswa yang masih belum memahami materi pembelajaran di kelas dapat berkonsultasi lebih lanjut dengan guru. Proses pembelajaran di kelas, guru dapat menjelaskan materi kepada siswa dengan berbagai model pembelajaran. Siswa dapat menanyakan secara langsung materi pembelajaran yang belum paham. Penerapan model pembelajaran Blended Learning siswa memiliki jam pelajaran tambahan melalui pembelajaran daring. Dalam pembelajaran daring siswa diberikan materi tambahan melalui ebook yang dibagikan melalui aplikasi telegram, video pembelajaran, serta artikel yang direkomendasikan guru untuk dipelajari oleh siswa. Pada saat pembelajaran di kelas siswa diberikan penjelasan kembali mengenai materi yang belum tuntas dibahas pada pembelajaran daring. Pemahaman siswa dapat diperkuat dengan adanya penjelasan materi dan soal-soal latihan yang diberikan oleh guru.

Perbedaan model pembelajaran pada kelas kontrol dan kelas eksperimen memiliki pengaruh yang signifikan terhadap hasil belajar siswa pada mata pelajaran Geografi. Dapat dilihat bahwa kelas yang menerapkan model pembelajaran Blended Learning memiliki hasil belajar yang cukup tinggi dibandingkan dengan kelas yang menerapkan model pembelajaran konvensional dengan face to face. Hal ini sejalan dengan pengungkapan (Aunurrohman, 2013) yang menegaskan bahwa penggunaan model pembelajaran yang tepat dapat mendorong tumbuhnya rasa senang siswa terhadap pelajaran, menumbuhkan dan meningkatkan motivasi dalam mengerjakan tugas, memberikan kemudahan bagi siswa untuk memahami pelajaran sehingga memungkinkan siswa mencapai hasil belajar yang lebih baik.

(Husamah, 2014) mengungkapkan hal yang sama bahwa implementasi blended learning dapat mengingkatkan hasil belajar peserta didik. Penelitian yang dilakukan sebelumnya juga mengatakan bahwa model pembelajaran Blended Learning dapat meningkatkan hasil belajar siswa. Penelitian juga dilakukan Syarif Izuddin tahun 2012 yang menunjukan bahwa terdapat perbedaan yang signifikan antara prestasi belajar siswa yang menggunakan model pembelajaran Blended Learning dan siswa yang menggunakan model pembelajaran face-to-face learning serta terdapat peningkatan prestasi belajar yang signifikan karena penerapan model pembelajaran Blended Learning. Hasil dari penelitian yang dilakukan oleh (Akkoyunlu \& Soylu, 2008) menunjukkan bahwa hasil belajar siswa dapat meningkat dengan tidak menghilangkan proses tatap muka di kelas. Dari hasil pengamatan yang dilakukan selama eksperimen, menunjukkan bahwa pelaksanaan model blended learning sejalan dengan pendapat (Kusni, 2010) yang mengungkapkan bahwa (1) pengajar perlu memiliki keterampilan dalam menyelenggarakan $e$ learning; (2) pengajar perlu menyiapkan referensi digital yang dapat menjadi acuan bagi peserta didik; (3) pengajar perlu merancang referensi yang sesuai atau terintegrasi dengan tatap muka; (4) pengajar perlu menyiapkan waktu untuk mengelola pembelajaran berbasis internet, misalnya untuk mengembangkan materi, mengembangkan instrumen asesmen dan menjawab berbagai pertanyaan yang diajukan peserta didik.

Dari hasil pengamatan, model blended learning dapat diterapkan dengan memperhatikan hal-hal berikut (1) pemahaman dan kesiapan guru dalam melaksanakan tahap demi tahap sesuai dengan aturan pada penerapan model pembelajaran Blended Learning; (2) pemahaman dan kesiapan siswa untuk melaksanakan kegiatan pembelajaran. Pemahaman dan kesiapan terhadap setiap tahap tahap dengan model pembelajaran Blended Learning sangat penting agar kegiatan pembelajaran berlangsung dengan lancar dan tujuan pembelajaran dapat tercapai; (3) tersedianya waktu yang cukup untuk melaksanakan langkah-langkah model blended learning. Terutama dalam penjadwalan pembelajaran daring yang harus disesuaikan dengan kemampuan siswa dan juga guru; (4) ketersediaan fasilitas dan bahan ajar yang dibutuhkan pada saat menerapkan model pembelajaran Blended Learning. Contohnya: tersedianya fasilitas internet yang memadai sehingga semua siswa dapat mengakses sumber belajar daring.

\section{SIMPULAN}

Berdasarkan hasil dari penelitian dapat disimpulkan bahwa model pembelajaran yang digunakan di SMA Islam Surakarta masih bersifat konvensional dan belum dapat dijadikan sumber belajar untuk mengembangkan pengetahuan siswa secara luas dan tanpa batas. Model pembelajaran Blended Learning dapat digunakan sebagai alternatif pembelajaran karena dapat dilaksanakan baik di dalam kelas maupun di luar kelas tanpa batasan tempat dan waktu. Penerapan model pembelajaran 
Blended Learning dapat meningkatkan hasil belajar siswa secara signifikan. Adapun saran dari peneliti sebagai berikut. Pertama, Acuan dasar dari penerapan model pembelajaran Blended Learning berasal dari hasil analisis kebutuhan atau keadaan, kondisi pada saat sekarang. Kedua, sebelum menerapkan model pembelajaran Blended Learning seharusnya memperhatikan materi yang akan digunakan agar lebih optimal dalam mencapai hasil pembelajaran. Ketiga, penelitian dengan model pembelajaran Blended Learning harus lebih memperhatikan kondisi yang memengaruhinya, yakni hasil dari kompetensi, tujuan pembelajaran, karakteristik peserta didik, strategi dalam penyampaian pembelajaran, lokasi, kemampuan pendidik serta ketersediaan sumber daya sebagai pendukung pembelajaran.

\section{DAFTAR RUJUKAN}

Akkoyunlu, B., \& Soylu, M. Y. (2008). A Study of Students Perceptions in a Blended Learning Environment Based on Different Learning Styles. Educational Technology \& Society, 11(1), 183-193.

Alfi, C., Sumarmi, S., \& Amirudin, A. (2016). Pengaruh Pembelajaran Geografi Berbasis Masalah dengan Blended Learning terhadap Kemampuan Berpikir Kritis Siswa SMA. Jurnal Pendidikan: Teori, Penelitian, dan Pengembangan, 1(4), 597602.

Fitri, E., Ifdil., \& Neviyarni. (2016). Efektivitas Layanan Informasi dengan Menggunakan Metode Blended Learning untuk Meningkatkan Motivasi Belajar. Jurnal Psikologi Pendidikan dan Konseling, 2(2), 84-92, https://doi.org/10.26858/jpkk.v2i2.2250

Graham, C. R. (2006). Blended Learning Systems: Definition, Current Trends, and Future Directions. Charles R. Graham, 13(10/11), 35. https://doi.org/10.2307/4022491

Heinze, A., Procter, C., \& Scott, B. (2007). Use of Conversation Theory to Underpin Blended Learning. International Journal of Teaching and Case Studies, 1(1/2), 108. https://doi.org/10.1504/ijtcs.2007.014213

Husamah. (2014). Pembelajaran Bauran Blended Learning) Terampil Memadukan Keunggulan Pembelajaran Face-to-Face, ELearning Offline-Online dan Mobil Learning. At-Turats, 9(2), 75. https://doi.org/10.24260/at-turats.v9i2.318

Ibrahim. (2017). Perpaduan Model Pembelajaran Aktif Konvensional (Ceramah) dengan Kooperatif (Make - a Match) untuk Meningkatkan Hasil Belajar. Ilmu Pendidikan Sains, 3(2), 199-212.

Jamaluddin, A. A., Dwiyogo, W. D., \& Hariyanto, E. (2018). Pembelajaran Senam Berbasis Blended Learning Guna Meningkatkan Hasil Belajar. Jurnal Pendidikan: Teori, Penelitian, dan Pengembangan, 3(2), 1373-1382.

Kusni, M. (2010). Implementasi Sistem Pembelajaran Blended Learning pada Kuliah AE3121 Getaran Mekanik di Program Studi Aeronotika dan Astronotika. Seminar Nasional Tahunan Teknik Mesin (SNTTM) Ke-9, 13-15.

Mujiono., Degeng, I. N. S., \& Praherdhiono, H. (2018). Pengembangan Pembelajaran Sistem Blended Berbasis Universal Design for Learning untuk Kelas Inklusif. Jurnal Pendidikan: Teori, Penelitian, dan Pengembangan, 3(6), $758-763$.

Mukminan. (2014). Inovasi Pembelajaran Geografi Tingkat Panitia Ardgiss In Motion (AIM) Fakultas Geografi UGM , 2014 Inovasi Pembelajaran Geografi Tingkat SMP dan SMA Dalam Kurikulum 2013. 0-14.

Qamar, K., \& Riyadi, S. (2018). Efektivitas Blended Learning menggunakan Aplikasi Telegram. At-Tajdid: Jurnal Ilmu Tarbiyah, 7(1), 1-15.

Sodikin., Noesasongko, E., \& Pramudi, T. C. (2009). Jurnal Penyesuaian dengan Modus Pembelajaran untuk Siswa SMK Kelas X. Jurnal Teknologi Informasi, 5(2), 740-754.

Sudarman. (2014). Pengaruh Strategi Pembelajaran Blended Learning terhadap Perolehan Belajar Konsep dan Prosedur pada Mahasiswa yang Memiliki Self-Regulated Learning Berbeda. Jurnal Pendidikan dan Pembelajaran, 21(1), $107-117$.

Waty, N. L., Sumarmi, S., \& Susilo, S. (2018). Peningkatan Kreativitas Belajar Peserta Didik pada Mata Pelajaran Geografi melalui Model Blended Learning di Sekolah Menengah Atas. Jurnal Pendidikan: Teori, Penelitian, dan Pengembangan, $3(1), 9-14$. 